This page intentionally left blank 


\title{
WHITE GUARD
}

\author{
MIKHAIL \\ BULGAKOV
}

Translated from the Russian by

MARIAN SCHWARTZ

With an Introduction by Evgeny Dobrenko

Yale University Press / New Haven \& London 
Translated from Mikhail Bulgakov, "Belaia gvardiia," in Izbrannye proizvedeniia v dvukh tomakh, edited by Lidiia Ianovskaia, vol. 1 (Kiev: Dnipro, 1989).

Copyright $\odot 2008$ by Marian Schwartz.

All rights reserved.

This book may not be reproduced, in whole or in part, including illustrations, in any form (beyond that copying permitted by Sections 107 and 108 of the U.S. Copyright Law and except by reviewers for the public press), without written permission from the publishers.

Designed by Mary Valencia Set in Minion by Tseng Information Systems, Inc.

Printed in the United States of America.

The Library of Congress has cataloged the hardcover edition as follows:

Bulgakov, Mikhail Afanas'evich, 1891-1940.

[Belaia gvardiia. English]

White guard / Mikhail Bulgakov ; translated from the Russian by Marian Schwartz ; with an introduction by Evgeny Dobrenko.

p. $\quad \mathrm{cm}$.

ISBN 978-0-300-12242-8 (alk. paper)

1. Ukraine-History-Revolution, 1917-1921-Fiction. I. Schwartz, Marian.

II. Dobrenko, E. A. (Evgenii Aleksandrovich). III. Title.

$$
\begin{gathered}
\text { PG3476.B78B513 } 2008 \\
891.73^{\prime} 42-\mathrm{dc} 22 \quad 2007050389 \\
\text { ISBN } 978-0-300-15145-9 \text { (alk. paper) }
\end{gathered}
$$

A catalogue record for this book is available from the British Library. 
To Liubov' Evgenevna Bulgakova 
A fine snow at first, suddenly it came in flakes. The wind howled. It was a snowstorm now. An instant later the dark sky had blended with the snowy sea. Everything disappeared.

"Well, sir," shouted the coachman, "looks bad. A blizzard!"

Alexander Pushkin, The Captain's Daughter

$\ldots$ and the dead were judged out of those things which were written in the books, according to their works.

REVELATION 20:12 